\title{
Rest Area Development in Central Java (Case Study: Rest Area on Semarang-Solo Toll Road)
}

\author{
Edy Darmawan ${ }^{1 *}$, Suzanna Ratih Sari ${ }^{1}$, Hermin Werdiningsih $^{1}$, Adhisti Samsinar Enis ${ }^{1}$ \\ ${ }^{1}$ Department of Architecture, Faculty of Engineering, Diponegoro University, Semarang, Central Java, Indonesia \\ *Email:adhis0601@gmail.com
}

\begin{abstract}
The construction of the road network is carried out to support the growth and acceleration of the economic process and the development of the tourism industry. It is also projected to improve the socio-economic conditions of the community. In the last few years, the Central Java Government has built toll roads to connect several cities in Central Java in one fast lane. However, it was not followed by the construction of supporting facilities such as rest area that serves a place to rest for motorists when they experience fatigue during long trips. The existence of the place is still limited, and it was not evenly distributed along the toll road, causing long queues at the entrance of some rest area when the volume of the vehicles is overflow. Based on these problems, the purpose of this research is to study and develop the requirement of rest area that can meet the needs of motorists traveling through the toll roads in Central Java. To achieve these objectives, this research used a qualitative descriptive method to describe and explain the problems in the field, and further analyze them to get a comprehensive result. The result of this research is presented in the form of published research reports and scientific articles. It is expected to provide benefits to the relevant scientific field, especially those related to architecture in developing rest areas that suit the needs of road users.
\end{abstract}

\section{Keywords}

Development; Rest areas; Toll roads; Central Java

\section{$1 \quad$ Introduction}

Economic development in an area is continuously carried out to develop economic activities and improve the standard of living of its people. In order to improve services and optimal development for an area, proper planning must be carried out to meet the completeness of transportation facilities and infrastructure. The existence of transportation infrastructure has an important role in supporting the successful development of an area. This infrastructure becomes the driving force for the wheels of trade and industry to turn around; two things that are at the core of economic development. The existence of infrastructure encourages not only the economic growth of a region but also provides an important influence in improving the quality of life and human welfare, as well as improving the socio-cultural conditions of people's lives. Infrastructure development has an impact on land use, which can later have an impact on various aspects of life [1]. In addition, the development of transportation infrastructure that improving the local economy positively is represented by the small and medium business sector in the area. The adequate transportation infrastructure can reduce transportation costs in products and provide opportunities for business actors to attract investors and expand marketing reach [1].
One of the government's steps to accelerate distribution and economic mobility in a region is using road network development. Toll roads are alternative roads that can accelerate transportation facilities, develop the tourism industry, support growth, and accelerate economic processes, which are often constrained by congestion and damage to road infrastructure. Through toll road construction, the flow of traffic within the city can be diverted to toll roads, so that road capacity in the city can be reduced and traffic flow within the city becomes seamless [2]. Therefore, in recent years, the government has made toll road construction as a top priority in national development in order to change the social and economic conditions of society in a better direction. In addition, the existence of toll roads is also expected to work together with arterial roads and collector roads to optimize economic growth.

This toll road construction project aims to connect several cities in Central Java in one fast lane. In 2014, the Central Java Government built six toll roads connecting Pejagan-Semarang-Solo-Mantingan and Semarang-Demak. The six toll roads have very long sections, and if the driver does not prepare the physical condition and condition of the vehicle to travel long distances, it will cause fatigue, which in turn can lead to accidents. Therefore, it is necessary to place the rest 
area according to the distance/interval that considers the needs of road users who will use it. The provision of a rest area is not only in the form of vacant land that is built modestly but also equipped with supporting facilities such as a food court, bathroom, prayer room, large parking area, workshop, garden with a sitting group, and other commercial facilities that can relieve fatigue during the trip. This is what makes the existence of a rest area highly important in supporting toll road development. However, the existence of a rest area on those toll roads is still limited and not evenly distributed, which cause frequent congestion at some point. The distribution of rest areas that is not incorporated with the length of toll roads can cause long queues at the entrance to the rest area when the volume of vehicles is high.

Based on these problems, this study aims to examine and suggest the development of rest areas in Central Java that can meet the needs of road users. With the availability of a rest area that suits the needs of road users, it is hoped that it can meet the objectives of toll road services for service users, namely smoothness, safety, and comfort. In addition, road users can rest comfortably to recharge during the trip.

\section{Literature Review}

\subsection{Rest area concept}

In general, a rest area is a place intended for road users to rest with the aim of improving road user safety or reducing the number of accidents caused by fatigue. This opinion was also conveyed by A. A. Fouad et al. [3], who said that a rest area that provides an opportunity for motorists to rest for a certain period of time can have an impact on aspects of the rest area ranging from design, parking space, size of facilities, water requirements, as well as the manufacture and handling of wastewater. Some research [4-6] also explained that a safe rest area is a rest area that provides facilities for comfort, a natural environment to unwind after driving, and information needs for road users. It should also be accessible and inclusive to accommodate people with special needs and have a safe environment; such as allowing children to play and providing fence between the rest area boundary and the surrounding. Therefore, the provision of a rest area must be equipped with supporting facilities that are tailored to the needs of road users, resources, and a sectoral master development plan for the local area, so that the provision of a rest area can be sustainable and able to meet the needs of road users. K. Rick et al. [7] stated that the provision of a rest area as a form of security and safety for road users must apply the concept of sustainability that can meet the needs of road users and conserve natural resources around it. To provide a rest area that is able to meet the needs of road users and is sustainable, it is necessary to consider the costs of building facilities, operational and maintenance costs that can provide optimal benefits and can reduce the burden on public costs borne by road users to support the rest area function in increase comfort, provide safety and convenience, and provide information facilities for road users [8]. The following are some rest area development concepts that have been carried out by previous researchers who are compiled as references in developing rest areas in Central Java:

- Conducted an economic assessment of rest areas in Queensland through an approach based on technical standards for rest areas, user comfort and safety, the growth in the number of vehicles so as to produce practical examples that can be applied in building a framework for evaluating challenges in rest area development [9].

- Analysis performed on the types of rest areas, rest area arrangements, and infrastructure for recreational facilities on Lithuanian roads. The rest area design must be open and available to all users and take into account the landscape, topography and vegetation in the area in order to have a function that is socio-economic, safe, and environmentally friendly [10].

- Applied the concept of earth-friendly to buildings and sites to achieve a balance between indoor and outdoor spaces so that the rest area can be integrated with nature and protect the surrounding environment [11].

- Buildings to be built in the rest area must adapt to the surrounding environmental conditions to create a rest area that is environmentally friendly and resource-efficient rest area [12].

- Applied the concept of regionalism which emphasizes the disclosure of the characteristics of a region or place in contemporary architecture and adapting it to the present era or making it more modern [13].

- Developed a rest area using a local architectural approach that is still thick with Bugis-Makassar customs and takes into account the relationship and proximity between facilities, ease of access and achievement [14]. 
- Apply the concept of road service pavilion in the development of rest areas, where the rest area is not only used as a resting place but also used as a node of interaction between local residents and road users that can encourage local economic development by using natural resources from the local area [15].

- Developed a commercial toll road rest area safety project for the government by focusing on understanding the physical and economic strength of each component such as economic factors that affect the feasibility of rest area development, design and layout factors, and design of transportation factors [16].

- Uses a sustainability strategy in rest areas by implementing green building designs through natural lighting, passive heating and energyefficient cooling techniques, and selecting sustainable materials, as well as implementing operational strategies that reduce energy and water use, reduce waste, minimizing environmental impact, use of renewable energy in rest area locations [17].

- Applies the concept of ecological architecture that utilizes natural resources efficiently and optimally so as to create a rest area that not only functions as a resting place for road users but also accommodates tourism and recreation activities for the community [18].

- The rest area is built by implementing servicescape has an influence on visitors in spending time in a rest area environment [19].

- The adequate distance between rest areas is 40-60 $\mathrm{km}$ which is equipped with supporting facilities [20].

- Applied the concept of circulation to the rest area with a "loop" system to make it easier for visitors and drivers to access all the facilities needed. This system is used to minimize the risk of congestion in the rest area [21].

- Applied the Michi no Eki concept which provides a rest area with high service quality and convenience for road users, further involves the participation of local communities in planning and management [22].

\subsection{Rest area in Indonesia}

The provision of rest areas on toll roads has been regulated in a study [23]. In this regulation, it is explained that a rest area or what is called a "Rest and Service Areas" is a rest area equipped with various public facilities that can serve all types of vehicles using the freeway for toll roads. Planning for the number and area of Rest and Service Areas is carried out by taking into account the need for services to toll road users during the licensing period and can be built in stages.

\section{Methodology}

The aim of this research is to study and develop rest areas in Central Java that can meet the needs of road users. For this reason, a qualitative descriptive research method is used, which can explain and describe the phenomena, problems, and potential of the rest area in Central Java. Precise and accurate information to solve the problems faced can be obtained through a qualitative descriptive method [24]. The research location is along the Semarang-Solo toll road, where the researcher observes the distribution and physical condition of the rest areas along the toll road. Data collection was carried out by observation of documentation, literature study, and interviews to determine the condition of the object, behavior patterns, and events that occurred in the area of observation [25]. The results obtained from this study are the concept of rest area development in Central Java which is obtained from observing the physical condition of the rest area and its supporting facilities, interviews with rest area users and managers, and analysis based on aspects of the prevailing laws and regulations.

\section{$4 \quad$ Results and Discussion}

\subsection{Rest area on Semarang-Solo toll road}

The Semarang-Solo toll road is a Trans Java toll road network which has a length of $\pm 72.64 \mathrm{~km}$. The construction of the Semarang-Solo toll road aims to connect the cities of Semarang, Salatiga and Surakarta, and to reduce traffic congestion in the Semarang and surrounding areas. To facilitate travel for toll road users, the Trans Java Toll Road on the Semarang-Solo section is preparing a rest area as a facility to support land transportation that supports seamless, safe, and comfortable toll performance. Based on the Toll Road Concession Agreement, there are several points of the rest area to be built along the Semarang-Solo toll road, as seen in Figure 1 below. 


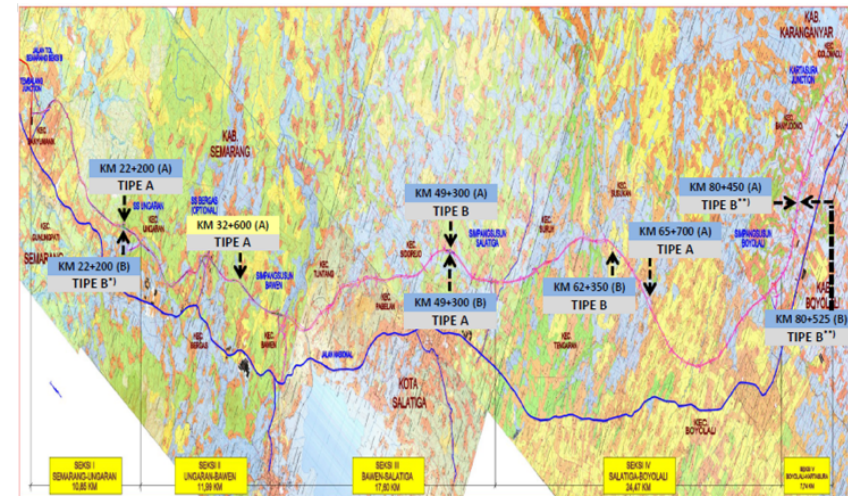

Figure 1 Rest and services development plan on the Semarang-Solo toll road [26]

Based on field observations, there are five rest areas on the Semarang - Solo Toll Road (See Figure 2). From all the rest areas, only one that was functioning properly, the other one was under construction, and the rest is still a temporary rest area. The rest area that can function properly and be equipped with supporting facilities for toll road users is located at KM 429 A. This rest area was crowded with toll road users in the morning and evening for them to unwind during the trip.
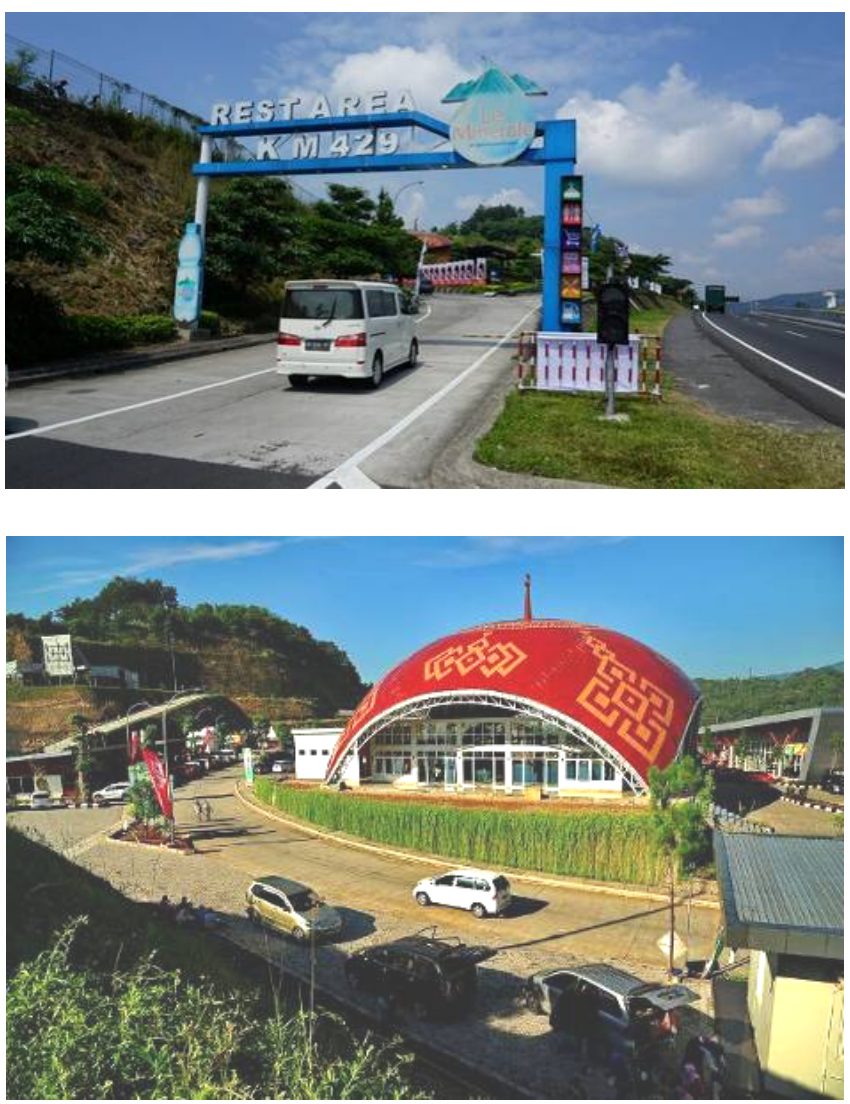

Figure 2 KM 429 rest area on Semarang-Solo toll road
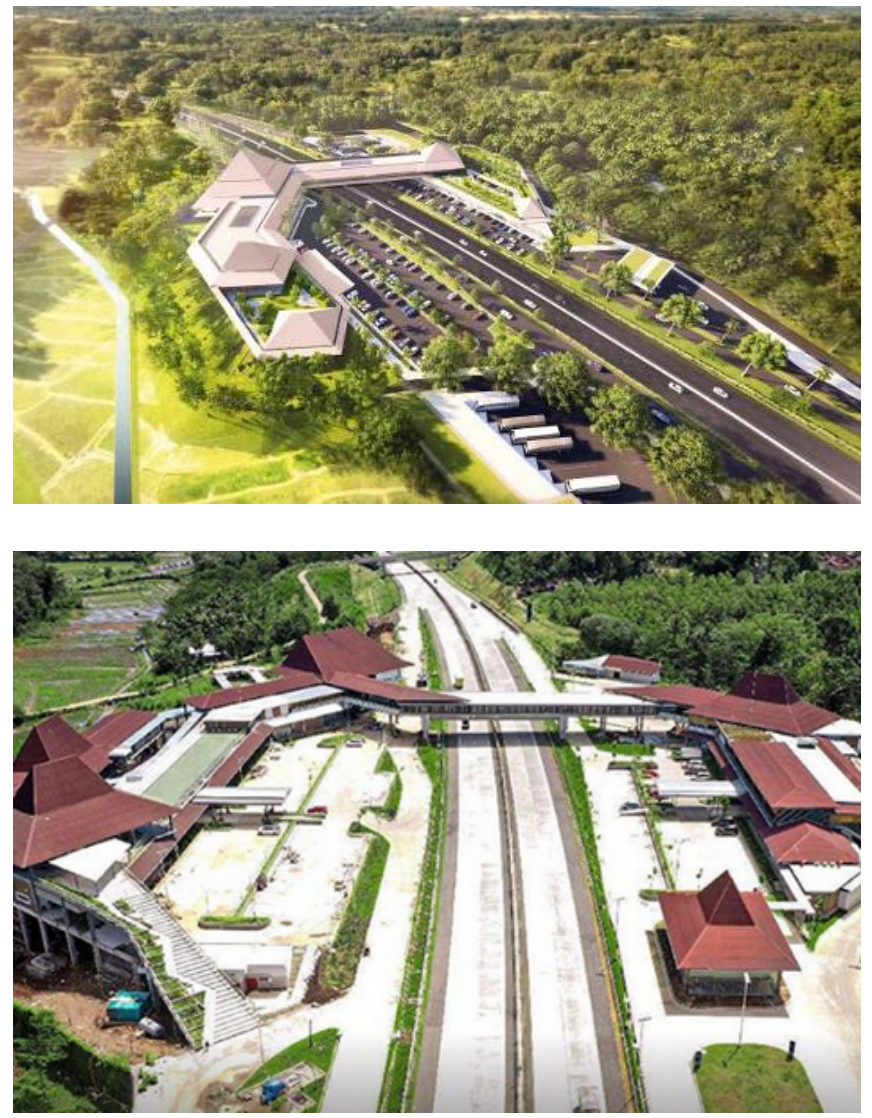

Figure 3 KM 456 rest area on Semarang - Solo toll road [27]

Temporary rest areas are located at KM $429 \mathrm{~B}, \mathrm{KM}$ 444 A, and KM 487 B (See Figure 4). This rest area was still empty but functional, only open during long holidays to accommodate the increasing road users. In the rest area, there are only public toilets, places of worship, merchant stalls, and parking lots that can be used by motorists. However, when it is crowded there are several traders selling food or drinks for road users. Some road users even spread out mats to take a break at this rest area. As stated in a study [13] that there is a positive relationship between road construction and an increase in the local economy, this is seen by the emergence of the temporary traders in rest areas during busy conditions. These traders mostly come from surrounding areas who try to make a profit by selling various types of goods for road users. 

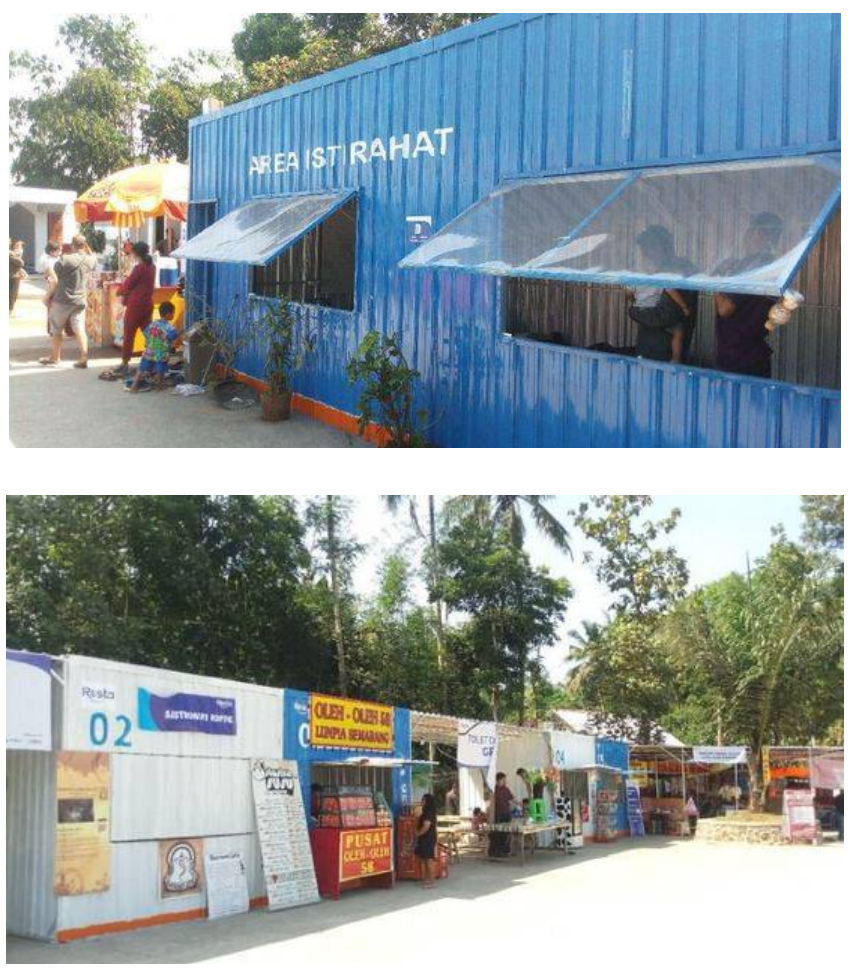

Figure 4 Temporary rest area on Semarang-Solo toll road

\subsection{Rest area function on Semarang-Solo toll road}

The construction of a rest area serves to provide a rest area for toll road users. Toll road users who feel tired after a long journey can visit this rest area to relax and unwind so that conditions feel fresher to continue the trip. Basically, a rest area does not only function as a place to rest but also has other functions which can be classified into main functions, supporting functions, and operational functions. The main function of the rest area is as a resting place for road users. This function can be seen in parking areas and eating places, where many vehicle users park their cars in the parking area to take a short break by sleeping or buying food and drinks at the place to eat. The supporting function of the rest area can be seen from its services to visitors by providing various supporting facilities that can meet the needs of visitors, such as toilets, places of worship, gift shops, places to eat, gas stations, and others. In addition, visitors can also enjoy the atmosphere and scenery that is served around the rest area. For operational functions, it is illustrated in the form of providing facilities and services, building maintenance, and all activities in the rest area. This can be seen from the presence of several cleaners who always clean every part of the rest area.

\subsection{Facilities at the Semarang-Solo toll road rest area}

Facilities are equipment provided to support activities that occur in a place. In the rest area, there are three functions, each of which has supporting facilities to provide services to rest area visitors. Based on a national regulation [23], there are 3 types of rest areas namely Type A, Type B, and Type C. The rest area on the Semarang - Solo Toll Road is included in Type A which must provide facilities in the form of a Center automated teller machines (ATMs) with toll card topup facilities, toilets, health clinics, workshops, stalls, minimarkets, prayer rooms, public gas stations, restaurants, green open spaces, and parking lots. All these facilities, if adapted to the function of the rest area, can be categorized as follows:

1. Main Functions of Facilities
a. Rest Area
b. Parking Area

2. Supporting Functions of Facilities
a. Place of Worship (Mosque/ Mushola)
b. Restaurant
c. Souvenirs Shop
d. Toilet
e. ATM Center
f. Mini Market
g. Gas Station
h. Information Center

3. Operational Functions of Facilities
a. Operations Office
b. Parking Area (for managers and employees)
c. Loading and unloading area

From observations in the field, the rest area that already has all of these facilities is in the KM 429 Rest Area (See Figure 5) because this rest area is the only rest area that is functioning properly and has even been awarded the Best Rest Area from the Ministry of Public Works and Public Housing in 2019. This rest area provides facilities that can meet the needs of toll road users, equipped with mini studio facilities as an information center, as well as a strategic location that offers attractive natural views. At the entrance to the rest area, visitors are greeted by a magnificent, modern-style domed mosque building. Inside the rest area, they will also find an attractive small garden near the coffee shop, then behind it, there is a hawker and souvenirs center selling various foods. 

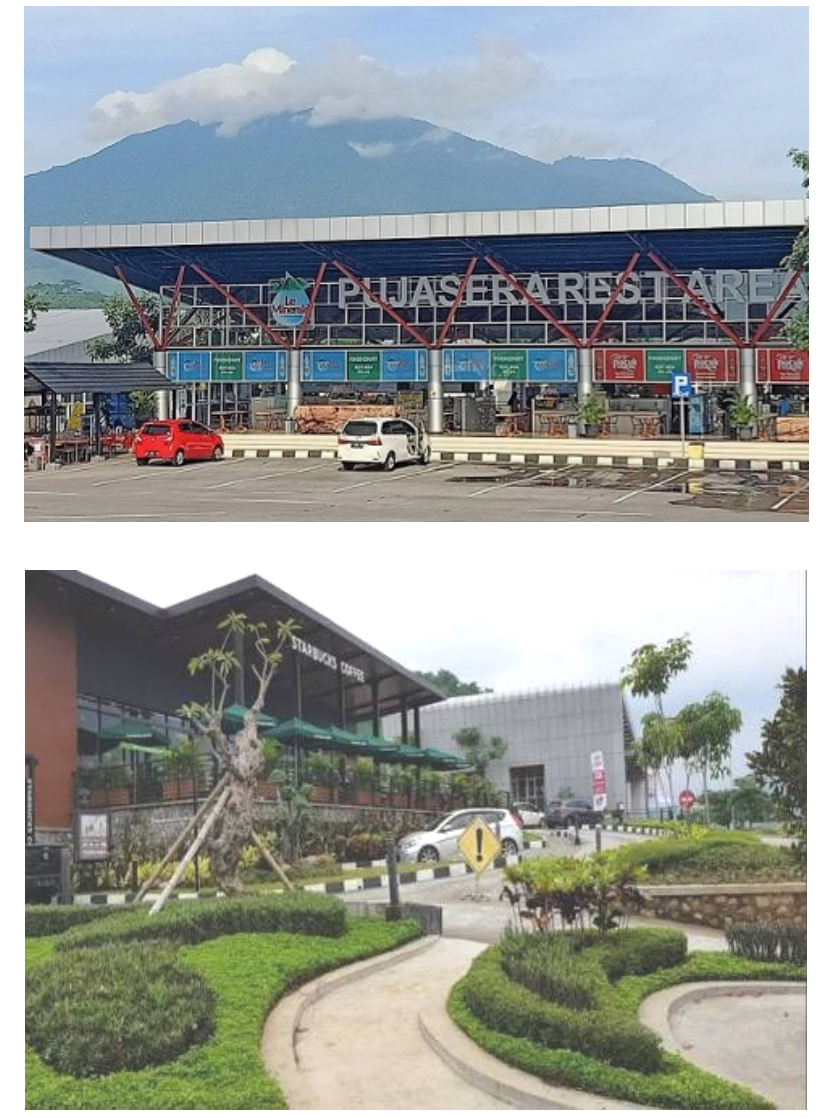

Figure 5 Facilities at KM 429 rest area SemarangSolo toll road

The KM 456 Rest Area which is still under construction (See Figure 6), will later be made for tourist destinations equipped with tourist objects, culinary spaces, retail spaces, cultural attraction spaces, green open areas, play and education areas, as well as worship facilities (mosques), toilets, parking lots, gas stations, galleries, and others. Thus, it is hoped that toll road users will have comfort while unwinding in this rest area. In addition, the existence of this rest area is expected to improve the economy around the toll road area.

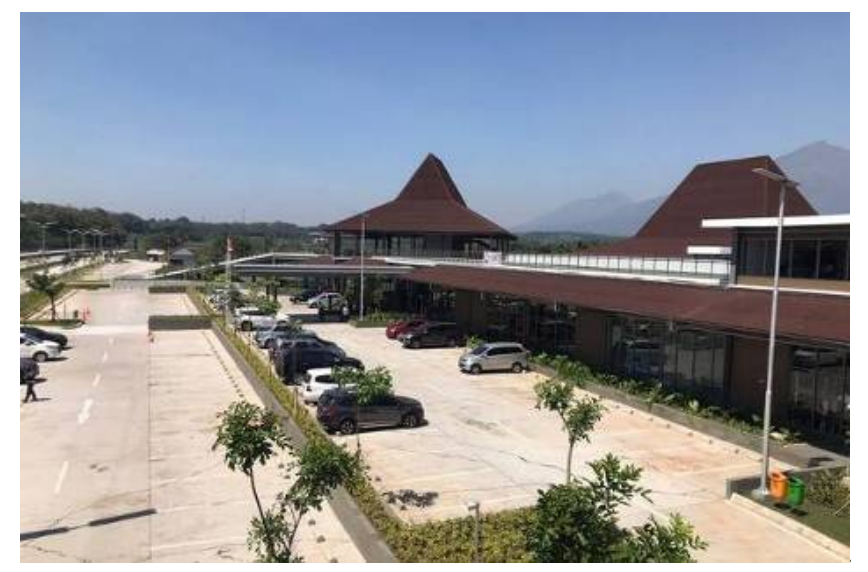

Figure 6 Facilities at KM 456 rest area Semarang Solo toll road

\subsection{Circulation and movement}

The rest area is a facility provided for road users to rest while traveling. Road users come from various groups with different purposes and various types of vehicles. For this reason, circulation and movement access in the rest area needs attention. The types of vehicles that enter the rest area consist of four-wheeled private vehicles, public transport (buses and minibuses), heavy vehicles (trucks and pick-up cars). At certain times, such as long holidays and holidays, the rest area will be crowded with road users, either with private vehicles, public transportation, and cargo vehicles. For this reason, parking and circulation access in the rest area must be considered carefully, considering the dimensions of each vehicle are quite diverse, especially loading goods vehicles that are classified as heavy vehicles.

\subsection{Rest area development in Central Java}

The function of a rest area, in general, is as a temporary rest area for road users. In its development, the rest area is not only aimed at optimizing the existence of toll roads and facilitating connectivity between regions but also to increase economic growth and develop the potential of the area around the rest area. The rest area will later be used as a public facility on the toll road corridor whose development concept involves related stakeholders. Currently, there are 4 rest area development concepts that are being reviewed by the Toll Road Regulatory Agency of the Ministry of Public Works and Public Housing. The rest area development concept consists of:

a) Rest area as a tourist destination, rest area development with this concept puts forward a beautiful view (scenic road) around the rest area.

b) The rest area as an intermodal transit area, the concept of developing this rest area aims to support the needs of Trans Java buses that can drop off passengers in the rest area so that passengers can continue their journey with other modes of transportation to their destination.

c) Rest areas as a logistics hub, namely the development of rest areas connected to important areas such as warehousing areas and industrial areas.

Of the three concepts previously described, it can be seen that the rest area on the Semarang-Solo Toll Road uses the rest area concept as a tourist destination. This is very possible considering the location of the rest area on the Semarang-Solo Toll Road is in an area that has a refreshing natural view for road users. The KM 429 A rest area is located in the highlands of Semarang Regency which has a beautiful view when the sun sets. 
Many toll road users stop by this rest area and capture the momentum of the sunset from Batu Park and the roof of the food stalls.

The rest area concept as a tourist destination is also applied to the KM 456 rest area. Even though it has not been $100 \%$ completed, the rest area which is built on an area of 10 hectares applies a design concept based on natural scenery that stretches along the Semarang - Solo toll road. The building in the rest area consists of five main buildings with a Joglo style inspired by Mount Merapi, Merbabu, Sumbing, Sindoro, and Ungaran. Between buildings will be connected to one another by a sky bridge. With the application of this concept, it is hoped that the rest area will not only be a fatigue relief facility but can also balance the business and social aspects in one place that can build an economic community in the area around the toll road.

Temporary rest areas can be developed into rest areas that can function optimally by considering the landscape, topography and vegetation in the area so that they have a safe, socio-economic and environmentally friendly function. The concept of development in this rest area can be done by utilizing local resources efficiently and emphasizing the disclosure of the characteristics of an area so that a balance is created between the building and the site. This will create a rest area that can be integrated with nature and save resources that can meet the needs of road users.

\section{Conclusion}

The rest area is one of the types of equipment provided to support activities that take place on toll roads. This also applies to the Semarang-Solo Toll Road. Based on observations in the field, it appears that there are 5 rest areas available on the Semarang-Solo Toll Road. The rest area has three functions, namely: the main function as a rest area for road users, support function that provides various facilities for the convenience of road users, and operational functions related to the provision of facilities and services, building maintenance. Of the five rest areas, only one has been functioning optimally with complete supporting facilities in accordance with the criteria for providing Type A rest area facilities, one is still in the construction stage, and the rest is still temporary and only functions at certain times when traffic flows on the road. However, the provision and development of rest areas on the Semarang-Solo Toll Road do not reduce the convenience of toll road users in utilizing it.

\section{Acknowledgement}

The author uses thanks to all those who have helped in collecting the data used in this article as part of our research objectives to get an idea of the concept of rest area development in Central Java that can meet the needs of road users. The authors would also like to thank the Ministry of Research and Technology of the Republic of Indonesia and Diponegoro University who have helped research so that this research can be carried out. Hopefully, this article can be useful for all parties related to providing rest areas.

\section{References}

[1] L. Rahayu and D. M. Kipuw, "The Correlation between Toll Road Development and the Improvement of Local Economy (Case Study: The Soroja Toll Road)," Int. J. Sustain. Transp. Technol., vol. 3, no. 1, pp. 26-36, 2020.

[2] N. S. Kardina et al., "Network Analysis of Intercity Bus Terminal and Inner-City Toll Road Development - The Case of Bandung City," Int. J. Sustain. Transp. Technol., vol. 3, no. 1, pp 8-18, 2019.

[3] A. A. Fouad et al., "Traffic Use of Rest Areas on Rural Highways: Recent Empirical Study," Transp. Res. Rec., vol. 2255, no. 1, 2011.

[4] F. G. Michael, "Review of Nonpublic Funding Options Available to the Virginia Department of Transportation for the Operations and Maintenance of Its Safety Rest Areas and Welcome Centers," Final Report VCTIR 11-R22, No. Pages: 106, Project No.: 97089. Virginia: Virginia Department of Transportation., 2011.

[5] T. J. Gates et al., "Evaluating the Appropriate Level of Service for Michigan Rest Areas and Welcome Centers Considering Safety and Economic Factors," Final Report MDOT ORBP Project Number: OR10-045. Detroit: Department of Civil and Environmental Engineering. Wayne State University., 2012.

[6] M. T. Sulastry, "Evaluasi Kemanfaatan Rest Area Dalam Jaringan Jalan Tol Antar Kota (Studi Kasus Rest Area Cikopo-Palimanan (Cipali))," JPTD., vol. 21, no. 1, pp 4758, 2018.

[7] K. Rick et al., "Assessment of Colorado Department of Transportation Rest Areas for Sustainability Improvements and Highway Corridors and Facilities for Alternative Energy Use," Final Report No. CDOT-2011-3. Colorado: Colorado Department of Transportation DTD Applied Research and Innovation Branch. Colorado State University., 2011.

[8] J. L. Carson et al., "Benefits of Public Roadside Safety Rest Areas in Texas," Report/ Paper Numbers: FHWA/TX-11/06267-2. Texas, United States: Texas Department of Transportation. Texas A\&M University., 2011.

[9] C. Shane, "The Economic Evaluation of Heavy Vehicle Rest Area - A New Technique?," Road Transp. Res., vol. 23, no. 1, pp 69-77, 2013.

[10] B. Lina, and J. Z. Lina, "Roadside Infrastructure and Rest Areas Concepts in Lithuania," in The 9th International Conference "Environmental Engineering 2014"., 2014.

[11] H. Y. Winata et al., "Rest Area di Jalan Lintas PekanbaruDumai dengan Pendekatan Arsitektur Hijau" JOM FTEKNIK., vol. 2, no. 2, pp.1-16, 2015.

[12] U. Agustinah et al., "Perencanaan dan Perancangan Rest Area Wilayah Suramadu di Kabupaten Bangkalan Madura (Tema: Arsitektur Berwawasan Lingkungan)," in National Seminar on Science and Technology Phase III., pp 617-626, 2015. 
[13] A. A. Brilliawan, "Perancangan Rest Area Tol Surabaya Malang di Kecamatan Purwodadi Kabupaten Pasuruan: Tema Regionalism Architecture", B.S. Thesis, Fac. Of Sci. and Tech., Maulana Malik Ibrahim Islamic State University Malang, Malang, Indonesia, 2016.

[14] Marwati et al, "Kawasan Peristirahatan dan Restoran Terapung di Ruas Jalan Poros Makassar-Malino," Nat. Acad. J. Architecture, vol. 3, no. 1, pp. 1-12. 2016.

[15] H. Pangihutan and H. Hendrawan, "Management Model of Resting Areas on Non-Toll Roads," J. Jalan Jembatan vol. 33, no. 2, pp. 116-128, 2016.

[16] P. H. A. Steel et al, "Investing in Highway Commercial Development: An Introduction to Alberta's Commercial Safety Rest Area Project," in TAC 2017 Investing in Transportation: Building Canada's Economy - 2017 Conference and Exhibition of the Transportation Association of Canada., 2017.

[17] U.S. Department of Transportation, "Sustainable Rest Area Design and Operations," Washington, D.C.: Federal Highway Administration. Office of Natural Environment", 2017.

[18] A. M. Habbib et al., "Rest Area di Perawang," Eng. J., vol. 12 , no. 1,2018
[19] J. Hyunsoon and Y. Y. You, "Impact of Korean Highway rest area Servicescape on the intention of Purchase," Int. J. Pure Appl. Math., vol. 118, no. 19, pp. 2295 - 2310, 2018.

[20] A. Romo-Martín and H. Pérez-Acebo, "Analysis of The Location of Service and Rest Areas and Their Facilities in Spanish Paying Motorways," Transp. Res. Proc., vol. 33., pp. 4-11, 2018

[21] E. Willy, "Rest Area di Kecamatan Seberuang Kabupaten Kapuas Hulu," JMARS., vol. 6, no. 2, pp. 141-156, 2018.

[22] M. Y. Lukman et al., "Perencanaan Rest Area dengan Konsep Michi-no Eki di Jalur Non-tol (Studi Kasus: Kabupaten Barru, Provinsi Sulawesi Selatan)," LOSARI, vol. 4, no. 2, pp. 67-76, 2019.

[23] Regulation of the Minister of Public Works and Housing No. 10/PRT/M/2018 concerning Rest and Services on Highway.

[24] Arikunto, "Research Procedure: A Practical Approach," Jakarta: PT Rineka Cipta, 2006.

[25] Sugiyono, "Understand Qualitative Research,", Bandung: Alfabeta Publisher., 2014.

[26] Transmarga Jateng [Online]. Available: www.transmargajateng.co.id, 2020. [Accessed on November 9, 2020].

[27] The Ministry of Public Works and Housing [Online]. Available: https://bpjt.pu.go.id/berita/skybridge-rest-areapendopo-456, 2020 [Accessed on November 9, 2020]. 